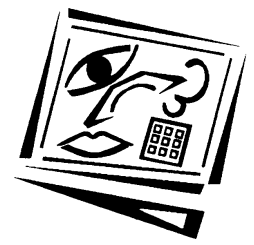

\title{
An examination of the role of the e-tutor
}

\author{
Annegret Goold, Jo Coldwell and Annemieke Craig \\ Deakin University
}

\begin{abstract}
As online learning environments continue to evolve, both teachers and students need to adapt to make the most of opportunities afforded by these environments for teaching and learning. The focus of this paper is on the changing role undertaken by tutors in online learning environments. We present a brief review of the current perspectives on the roles and responsibilities suggested for the e-tutor for effective teaching, and then report on a study where roles of e-tutors in a large wholly online unit were examined. The study supports the view that although the role of the e-tutor is similar to that of the face to face tutor in some respects, there are sufficient differences to make e-tutoring challenging to those who have not undertaken such online activities previously. Ongoing professional development is required to meet the changing demands of the technological environment, as well as the changing needs of students.
\end{abstract}

\section{Introduction}

Over the last two decades teaching in most Australian tertiary institutions has shifted from a purely face to face environment to one which is online or a blending of the two. Online environments continue to evolve as newer technologies make more sophisticated online delivery possible. Current online learning environments (OLEs) support interactivity, communication, participation and collaboration, as well as student engagement in authentic learning tasks.

While these online environments continue to change, the desire to ensure effective student learning is taking place remains. Ramsden (1992) argues that effective teaching facilitates effective learning by students. Consequently the quality of the teaching is important in any learning environment to ensure that outcomes for students are optimal. Strategies for successful teaching require teachers to continually adapt to the learning environment within which they operate (Salmon, 2002). Wilson and Stacey (2004) and Dixon, Dixon and Axmann (2008), among others, suggest that the provision of professional development for academic staff is continually required as OLEs develop and change.

The overall aim of this study was to identify characteristics of effective tutors in online learning environments. In this paper the roles of e-tutors as described in the literature were reviewed. These roles were then compared to those adopted by teaching staff in a large, wholly online unit at an Australian tertiary institution. The lessons learned from this study have highlighted implications for teaching practice in such online learning environments. 


\section{Background}

According to the National Tertiary Education Union (NTEU) the use of casual staff in the tertiary education sector in Australia is increasing. Over the period 1995 to 2005 casual staff increased by $54 \%$ while permanent staff increased by $23 \%$ (NTEU, 2007). NTEU suggests that the increasing use of casual staff to fulfil teaching commitments has resulted from the devolved budget models currently popular in tertiary institutions.

The traditional learning environment in Australian higher education encompasses face to face teaching with lectures delivered by academics. Tutorials and practicals delivered to smaller classes of students may be facilitated by academics but are more often than not conducted by tutors employed on a casual basis. In many cases a similar administrative structure is being applied to teaching in the OLE where the online content and learning activities are devised by the academics; whereas the e-tutor - also known as the online tutor or e-moderator - is directed to facilitate student activities. In many online classrooms the e-tutor will therefore be a different person than the teacher in charge.

The division of tasks between content production and learning facilitation is clearly demonstrated by the model that online distance education providers in the United Kingdom and Canada have adopted (Coldwell, 2009). Academics at the UK Open University are responsible for creating the learning resources that students will use in their studies. Online tutors are employed to facilitate students' learning during their studies. Generally academics do not interact with the students. Athabasca University in Canada has a similar model of content development and online tutorial support. Since these institutions do not have fixed term dates, utilising communication and collaboration amongst students as part of the learning experience is rare (Coldwell, 2009). Australian institutions however, do have well-defined teaching periods which support cohorted student groups and thus allow online communication and collaboration between students to be used as part of the learning environment. This has considerable impact on the role that e-tutors are expected to undertake in the OLE.

\section{The role of the e-tutor}

A case study undertaken by Cosetti (2000) found that the traditional knowledge required by the university tutor was insufficient for the e-tutor, since interacting via an online environment is very different from interacting in a face to face classroom. O'Neil (2006) suggests that 'online instructor's role requires a paradigm shift in perceptions of instructional time and space, virtual management techniques and ways of engaging students through virtual communications'. White, Murphy, Shelley and Baumann (2005; p. 83) agree and argue that tutors and e-tutors are very different 'in terms of the roles they assume and the ways they interact with students, and the attributes and expertise required of them'. The online tutor-facilitator has a unique role that 'requires a wholly new range of skills that arise from the cyber-dynamics of the online world' (Cox, Clark, Heath \& Plumpton, 2000; p.2).

Salmon (2003) defines the person who is responsible for responding to and building on the contributions of online discussions as an e-moderator. She suggests that the emoderator should facilitate the learner's transition into the online learning environment as well as through the complexities of the learning activities. In the last 30 
years education theory has shifted to advocate a constructivist theory of learning ( $\mathrm{Ng}$ \& Cheung, 2007) where the role of the university professor is 'the guide on the side' rather than the 'sage on the stage' (King, 1993). Collison, Elbaum, Haavind and Tinker (2000) propose that this is also the most appropriate role for leading a virtual learning community. They suggest that the tasks of an online instructor or e-tutor should include: being aware of all postings within discussion forums; encouraging participation and keeping track of the involvement of individual students; keeping the discussion focused; and encouraging higher order thinking. However Cox et al. (2000) suggest that the unique role of the e-tutor requires continual reappraisal in an environment where technology change is constant.

Denis, Watland, Pirotte and Verday (2004) have attempted to define the profession of e-tutoring with a list of seven roles that they consider paramount for e-tutors to be able to manage in their interactions with students in the online classroom (see Table 1). There is a distinct overlap between these roles and those recommended by Goodyear, Salmon, Spector, Steeples and Tickner (2001) for the roles of online teachers, suggesting a blurring of the boundaries of these roles.

Table 1: Roles of e-tutors

\begin{tabular}{|l|}
\hline \multicolumn{1}{|c|}{ E-tutor roles } \\
\hline 1. Content facilitator \\
\hline 2. Metacognition facilitator \\
\hline 3. Process facilitator \\
\hline 4. Advisor/counsellor \\
\hline 5. Assessor \\
\hline 6. Technologist \\
\hline 7. Resource provider \\
\hline
\end{tabular}

Incorporating Berge's (1995) categorisation of tasks (pedagogical, social, managerial and technical) as necessary for successful e-tutoring, the European Union E-tutor project (Directorate-General for Education and Culture, 2004-2005) has developed a model for e-tutoring which incorporates the interrelationships between the various roles as shown in Figure 1.

Cheung and Hew (2008) argue that the individual characteristics of the e-tutor are reflected in their contributions to online discussions. They refer to 'habits of mind', the attributes of facilitators such as: awareness of own thinking; accuracy seeking; openmindedness; taking a position; and being sensitive to others - all of which influence how they interact with learners in online discussions and to what extent different roles are exemplified. In subsequent research using two case studies, 'aware of thinking' and 'open minded' were the most prevalent habits of mind (Cheung \& Hew, 2010).

The reality of the contemporary educational environment is that different characteristics of roles may need to be combined to address specific e-learning contexts (Brown, 2002). Lim and Lee (2008) suggest that three categories are sufficient: technical, managerial and facilitator. However this does not take pedagogy or content into account. Kim, Lee and Lim (2010) proposed four role domains - cognitive or intellectual, managerial or organisational, social and technical. Regardless of how roles are categorised, students have different expectations of how staff will engage online (Craig, Goold, Coldwell \& Mustard, 2008). 


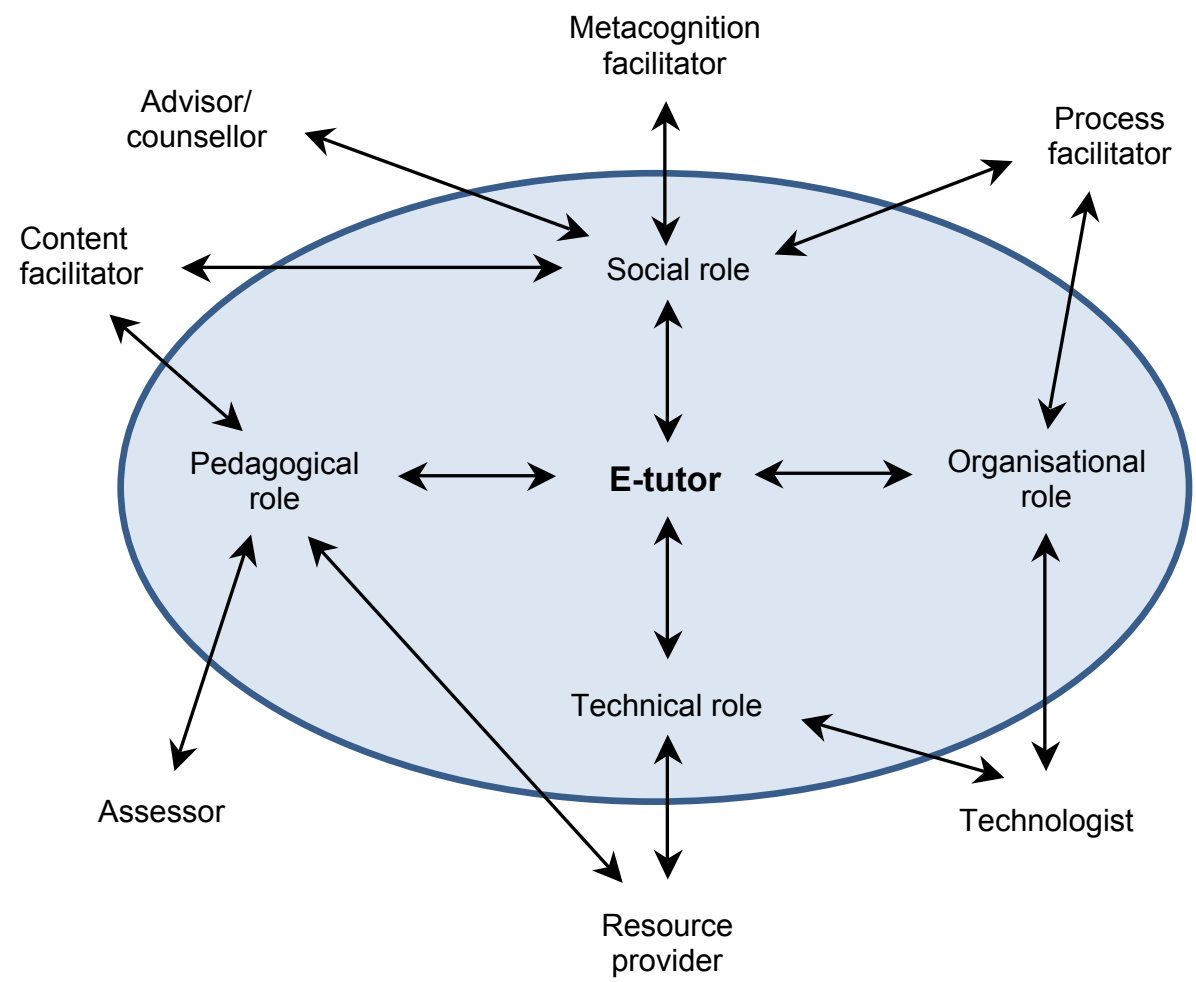

Figure 1: Combined e-tutor role model

\section{Context of the study}

At Deakin University a standard undergraduate degree program is made up of 24 units of study normally completed over three years. Within every undergraduate program at least one of these units must be delivered wholly online. This is a directive of the University. In wholly online units, there are no face to face components and all teaching takes place in the OLE. The purpose of such wholly online units is to prepare students for lifelong learning by developing their skills in online communication and collaboration. One of the constraints of such wholly online units is that face to face consultation is not available to students.

The wholly online unit investigated here is a third-year unit within the Bachelor of Information Technology. The unit aims to provide students with an understanding of how information technology professionals work in practice, and to equip students with the skills to apply this understanding to real world situations. The unit does not have a formal exam. Group discussions in forums are important learning activities and the individual contributions made by students are assessed as part of the unit. These discussions contributed $25 \%$ of the assessment of the unit overall.

The unit curriculum is divided into four modules, each focusing on different aspects of information technology practice. These three-week modules are: 
Module 1: IT Employment

Module 2: IT Teams

Module 3: IT Projects

Module 4: IT Professional Practice.

Each module requires students to engage with the learning materials and resources in the OLE and to participate in group discussions facilitated by the e-tutor. In Module 2 and Module 3 students also interact with a virtual fictitious organisation and engage in further discussion as part of that organisation's intranet. These discussion postings are not part of the OLE. This is done deliberately to distinguish between the students' learning space and the virtual work environment. In the virtual work environment the discussions are between members (students) of the teams and also between students and tutors who take on the role of the teams' project manager. The postings to the intranet discussions are not included here. The postings to two other discussion forums available to all students in the OLE - one moderated by the Unit Chair and a social space - have not been included either. Thus only the contributions to the OLE discussions involving e-tutors were examined.

Three cohorts of students in different offerings of the unit were studied. The teaching periods were of twelve weeks duration with trimesters beginning in March 2008, July 2008 and March 2009. Six individual e-tutors were involved. Two were academic teaching staff while the other four were postgraduate students who had taken up tutoring on a casual basis. The type of teaching expected by e-tutors in this online unit was similar to a position of instructor in a face to face context. The e-tutors did not design nor provide any teaching resources or learning activities. Although they did assess student work, this assessment was done under the supervision of the academic teachers. The latter are ultimately responsible for the design and delivery of the curriculum and the student assessment.

In this unit different e-tutors were responsible for each of the modules across the whole class. For the duration of each module (three weeks) they were the sole e-tutor for the cohort. They were involved with marking assessment tasks for a further two weeks after the completion of the module. This type of allocation allows flexibility for all of the teaching staff but particularly for the postgraduate students who effectively work intensively for a period of about five weeks and then have time for their own studies for the remainder of the teaching period. It also means that there is equity of teaching and moderation of assessment for all students since they have all had the same teaching staff involved.

\section{Results and discussion}

There were varying numbers of groups in each of the teaching periods, with 16 groups in teaching period 1 (TP1) and teaching period 3 (TP3), and only eight groups in teaching period 2 (TP2). There were similar numbers of postings by e-tutors and students for Groups 9 to 16 for TP1 and TP3, but for ease of comparison of results only postings for each module across Groups 1 to 8 for each period have been included. Table 2 shows the number of students who participated in each module together with the number of postings made by both students and e-tutors in the discussion forums for each module. 
Table 2: Postings for each Module across eight groups and over three periods

\begin{tabular}{|c|c|c|c|c|c|c|c|c|c|}
\hline \multirow{2}{*}{ Module } & \multirow{2}{*}{$\begin{array}{l}\text { No. of } \\
\text { students }\end{array}$} & \multicolumn{2}{|c|}{ Postings TP1 } & \multirow{2}{*}{$\begin{array}{l}\text { No. of } \\
\text { students }\end{array}$} & \multicolumn{2}{|c|}{ Postings TP2 } & \multirow{2}{*}{$\begin{array}{l}\text { No. of } \\
\text { students }\end{array}$} & \multicolumn{2}{|c|}{ Postings TP3 } \\
\hline & & Student & E-tutor & & Student & E-tutor & & Student & E-tutor \\
\hline 1 & 75 & 161 & 52 & 79 & 270 & 63 & 77 & 590 & 59 \\
\hline 2 & 72 & 462 & 143 & 78 & 535 & 75 & 72 & 623 & 81 \\
\hline 3 & 79 & 291 & 70 & 82 & 278 & 42 & 75 & 422 & 66 \\
\hline 4 & 79 & 508 & 128 & 76 & 454 & 111 & 66 & 428 & 215 \\
\hline Total & 305 & 1422 & 393 & 315 & 1537 & 291 & 290 & 2063 & 421 \\
\hline
\end{tabular}

The investigation of the e-tutor role in practice centred on the types of messages that were posted in the discussion forums by the tutors. One of the researchers classified the messages into four categories: content facilitator, social, managerial and technical. The coding was verified by the research team by reviewing the coding of a sample of messages. The categorisation of the discussion postings was based on the four key roles as shown in Figure 1, but these roles were rephrased to the terms suggested by Hootstein (2002) and supported by Kim et al. (2010). Each posting was counted in one of the four categories. In cases where a posting could be classified in more than one category, it was scored as a fraction of each. Table 3 shows the classification of the etutor postings for the four modules.

Table 3: Postings for each Module by e-tutors across eight groups

\begin{tabular}{|c|c|c|c|c|c|c|c|c|c|c|c|}
\hline $\begin{array}{c}\text { Teaching } \\
\text { period }\end{array}$ & Module & \multicolumn{2}{|c|}{ Content } & \multicolumn{2}{|c|}{ Social } & \multicolumn{2}{|c|}{ Managerial } & \multicolumn{2}{|c|}{ Technical } & \multicolumn{2}{|c|}{ Total } \\
\hline \multirow[t]{4}{*}{1} & 1 & 6 & $12 \%$ & 0 & $0 \%$ & 45 & $88 \%$ & 0 & $0 \%$ & 51 & $100 \%$ \\
\hline & 2 & 10 & $7 \%$ & 0 & & 123 & $86 \%$ & 10 & $7 \%$ & 143 & $100 \%$ \\
\hline & 3 & 17 & $25 \%$ & 3 & $4 \%$ & 49 & $71 \%$ & 0 & $0 \%$ & 69 & $100 \%$ \\
\hline & 4 & 60 & $47 \%$ & 2 & $2 \%$ & 67 & $52 \%$ & 0 & $0 \%$ & 129 & $100 \%$ \\
\hline \multirow[t]{4}{*}{2} & 1 & 13.5 & $21 \%$ & 1 & $2 \%$ & 48 & $75 \%$ & 1.5 & $2 \%$ & 64 & $100 \%$ \\
\hline & 2 & 10 & $13 \%$ & 0 & $0 \%$ & 64 & $85 \%$ & 1 & $1 \%$ & 75 & $100 \%$ \\
\hline & 3 & 0 & $0 \%$ & 0 & $0 \%$ & 42 & $100 \%$ & 0 & $0 \%$ & 42 & $100 \%$ \\
\hline & 4 & 8 & $7 \%$ & 0 & & 100 & $92 \%$ & 1 & $1 \%$ & 109 & $100 \%$ \\
\hline \multirow[t]{4}{*}{3} & 1 & 6 & $10 \%$ & 9.5 & $16 \%$ & 43.5 & $74 \%$ & 0 & $0 \%$ & 59 & $100 \%$ \\
\hline & 2 & 0 & $0 \%$ & 4 & $5 \%$ & 76 & $94 \%$ & 1 & $1 \%$ & 81 & $100 \%$ \\
\hline & 3 & 4 & $6 \%$ & 6.5 & $10 \%$ & 54.5 & $83 \%$ & 1 & $1 \%$ & 66 & $100 \%$ \\
\hline & 4 & 68 & $32 \%$ & 4 & $2 \%$ & 143 & $66 \%$ & 0 & $0 \%$ & 215 & $100 \%$ \\
\hline Total & & 202.5 & $18 \%$ & 30 & $3 \%$ & 855 & $78 \%$ & 15.5 & $1 \%$ & 1103 & $100 \%$ \\
\hline
\end{tabular}

The table of e-tutor postings (Table 3) clearly shows that the vast majority of postings were managerial in nature. Here e-tutors were responding to queries from students who were unsure about tasks and needed to be directed to the appropriate resources. In some instances, although e-tutors responded to postings at least twice a day, other students in the same group often answered their queries.

An example of a managerial posting is (UE is the name given to the virtual organisation; DSO is Deakin Studies Online):

Tasks 1 to 4 are now complete, great work! Work can begin on task 5. Make sure you note the completion date. Please remember that Debbie does not have access to DSO, therefore any communication regarding task 5 must take place on UE to be considered for assessment. All the best for the rest of this unit! 
There were few messages about technical issues in any of the modules in any of the teaching periods. This is to be expected since students were in their final year of study in an IT course and were familiar with the OLE and the technologies. Any messages relating to technical issues would probably have been posted early in the teaching period in the general discussion forum moderated by the Unit Chair. It should be noted that IT students generally cope well with technical issues and are more often than not able to resolve them with little or no assistance.

The low number of social postings is not unexpected either, since there was an alternative social space for students to have conversations unrelated to unit work. Further, in the modules under investigation sometimes a short social comment was included in other messages. These short social postings were not extensive enough to warrant inclusion in the final tally. An example of a social posting is: 'You certainly have got on with the task at hand. Good work, keep it up.'

Content postings are those that provide information and support students in gaining an understanding of that information. An example of a content posting is:

\begin{abstract}
Several amongst you have recently "discovered" the Australian Computer Society code of ethics (the Australian formulation of a code of conduct for IT professionals) and were surprised at the relevance of them to workplace issues! The code has been designed in collaboration with the industry and reflects expected behaviour of people working in the industry. As I've pointed out above, the professional component is the same regardless of which industry you are in. The codes define expected levels of behaviour. Your actions, knowledge and actual work is only coloured by the discipline.
\end{abstract}

What is surprising is the relatively low number of postings relating to content in many of the modules over the three offerings. For example, in TP1 there were six postings for Module 1 and 10 postings for Module 2. There were only four instances where the number of content messages exceeded $20 \%$ of the e-tutor postings - in TP1 for Modules 3 and 4; in TP2 for Module 1; and in TP3 for Module 4. The highest number of content messages occurred in TP1 in Module 4 with 60 postings (47\% of the total). The overall result of $202.5(18 \%)$ postings is contrary to Harris and Sandor's claim that 'in common with the traditional model of learning, there remains an onus upon the instructor to be extensively involved in the dialogue of course content' (2007; p.384).

An argument could be put that the number of messages in each category would be closely related to the type of learning activities students were completing. This is true across each module but the learning activities in the same module in the three teaching periods were the same. This does not explain the considerable differences noted in Module 4 and to a lesser extent in Module 3 between teaching periods (see Table 4).

Table 4: Summary of postings for Module 4

\begin{tabular}{|c|c|c|c|c|c|c|c|c|c|c|}
\hline $\begin{array}{c}\text { Teaching } \\
\text { period }\end{array}$ & \multicolumn{2}{|c|}{ Content } & \multicolumn{2}{c|}{ Social } & \multicolumn{2}{c|}{ Managerial } & \multicolumn{2}{c|}{ Technical } & \multicolumn{2}{c|}{ Total } \\
\hline 1 & 60 & $47 \%$ & 2 & $2 \%$ & 67 & $52 \%$ & 0 & $0 \%$ & 129 & $100 \%$ \\
\hline 2 & 8 & $7 \%$ & 0 & $0 \%$ & 100 & $92 \%$ & 1 & $1 \%$ & 109 & $100 \%$ \\
\hline 3 & 68 & $32 \%$ & 4 & $2 \%$ & 143 & $66 \%$ & 0 & $0 \%$ & 215 & $100 \%$ \\
\hline Total & 136 & $30 \%$ & 6 & $1 \%$ & 310 & $68 \%$ & 1 & $1 \%$ & 453 & $100 \%$ \\
\hline
\end{tabular}


On closer inspection of the content-related messages it was noted that many were in direct response to a student enquiry, except in the case of Module 4 in TP1 and TP3 where approximately half of the content messages were initiated by the e-tutor, rather than as a direct response to a student query or message. The content was the same in each period for this module, so a different factor was at play here. In fact, the data highlights the distinction between experienced e-tutors and those with limited etutoring experience. The discussions for Module 4 in TP1 and TP3 were moderated by a member of the teaching staff who is a highly experienced online teacher and who had been involved in the design of the unit. In Period 2 the module was moderated by one of the less experienced (novice) e-tutors.

The finding here that the frequency of discussion posting is noticeably less for novice e-tutors is supported by Morris, Xu and Finnegan (2005, as cited in McQuiggan, 2007). In their qualitative study of 13 e-tutors they found that the frequency of postings of three novice e-tutors was much lower (average of 19 postings) than the frequency of postings by experienced e-tutors (average of 193 postings). Our data in Table 4 does not have the same level of variation. For example, Module 4 had 129 postings in TP1 and 215 postings in TP3 compared with 109 postings in TP2 when the module was moderated by a novice e-tutor.

Revisiting the messages posted by novice e-tutors revealed that these tutors focused on ensuring students completed the requirements of the assessment, reminding them about deadlines and the need for timely participation, as well as assisting them by organising the discussion threads. The difference in the types of postings by novice and expert e-tutors is supported in the literature. In a study of postgraduate students undertaking an e-learning unit, Maor (2008) found that students who took on the role of discussion leader behaved differently from the online teacher. The discussion leader focussed on summing up and confirming; focusing discussion; moving the discussion forward; and debriefing. The teacher on the other hand tended to give more direct instruction/content related postings and gave more encouragement and feedback. Kaur, Fadzil and Ahmed (2005) found that online tutors were supportive in motivating and communicating with students but were ineffective in engaging the learner, knowledge building, encouraging high-order thinking, fostering collaboration and technology support. Ellis, Goodyear, O'Hara and Prosser (2007) stress that students must be supported in making the connections between discussions and what they are supposed to be learning.

Our study shows that while the experienced e-tutor was able to undertake a number of roles in an e-learning context, the main focus was on encouraging the students to engage with the learning resources and activities beyond what was specified in order to promote deep learning. The experienced e-tutor was able to provide the scaffolding for students in their understanding of the content. Novice e-tutors, on the other hand, did not do this. Generally their focus was not on the quality and depth of the learning experience. This is really not unexpected since this type of tutoring experience is one that the majority of the e-tutors here had as students. They had completed their undergraduate studies in IT at this institution and had completed this unit as part of their studies. According to Conrad (2004, as cited in McQuiggan, 2007; p.6) 'when learning to teach online, faculty will rely heavily on their past classroom teaching experiences'. Consequently a major discrepancy has emerged between the expectations by teaching staff of e-tutors and the capabilities and actions of tutors as e-tutors. This gap must be addressed if the expected learning outcomes of the online unit are to be fully realised. 
A significant difference between face to face support for learning and online learning is the ubiquitous lecture. At our institution, lectures are delivered by discipline experts and students are provided with content and given direction as to what they need to do and how to do it. In the online environment such explicit direction is not forthcoming. The learning resources in the OLE may well be electronic sources, readings and study guides where the onus is on the student to navigate their way through the curriculum. The onus is then on the e-tutor to assist them when they get stuck or lose their way. However, in the online environment both students and novice e-tutors seem to be more assessment oriented, with their focus on completing tasks rather than on learning and understanding content. Furthermore, tutors are not necessarily content experts, nor do they have the same commitment to learning objectives that a member of the teaching staff would have. It is imperative that e-tutors do challenge students in order for them to learn effectively.

A further difference between face to face tutorials and online tutorials is the size and number of sessions a tutor is responsible for. In a face to face situation there may be 20 to 25 students in the class with each of these classes likely to be divided up into smaller discussion groups. Each tutorial is normally of two hours duration with the tutor responsible for guiding students through the tasks. As most full time postgraduate students are limited to approximately six hours of employment per week, they would be responsible for two or three classes each from the same unit. Much of this time would be taken up with listening to the students and intervening only when necessary or asked. In the OLE the groups are designed to be 'discussion' group sized - about 10 to 12 students per group. The 'listening' task takes more time as listening in an online context involves reading all student postings.

Further, in order to maintain consistency in teaching and assessment within each module, e-tutors are responsible for all groups in one module rather than a subset of groups across all modules. This horizontal division of labour across the curriculum rather than a vertical division through the class means that there is considerable repetition in tutoring activities. The e-tutor's job is intensive and time consuming over a few weeks rather than being evenly spread across the whole teaching period. On the other hand, the e-tutor does not have to monitor each group for two hours at a time, but can drop in regularly at times when the students are likely to be active in their online discussion forums. The idea that a tutor might be responsible for 10, 15 or even more groups in a face to face environment is unheard of; yet in an online environment it is not uncommon. Even from an administrative perspective in this particular unit, the demands placed on the e-tutor are quite different from those placed on a tutor in a face to face class.

The novice e-tutors in this study completed their apprenticeship through the IT regime where tutors are in fact glorified demonstrators who support students on managing the technical aspects to complete a set task. Generally tutors do not teach; they guide students through the practical activities that have been created by the teaching staff. One of the assumptions that the teaching staff are making about novice tutors is that they can adjust and adapt from their previous experiences of learning as a student, both in face to face classes and online.

\section{Recommendations}

The insights gained from this study regarding the competency of tutors to become effective e-tutors have directed us to a number of recommendations for professional 
development for the e-tutor and for best practices for teaching online. Targeted professional development is required as well as extensive tutor support beyond what would normally be expected in a face to face environment. Novice e-tutors need to be guided and trained to direct students' online communication and collaboration in ways that will ensure that learning objectives are being met. Supporting novice tutors by having them work with a group or team of different experts such as instructors, facilitators, technicians, developers and instructional designers has appeared to work well in an online research course (Mortera-Gutiérrez, 2008).

In face to face classes, teaching staff involved with units with multiple tutors generally develop a lesson plan for tutors to use to maintain consistency and to provide advice and directions on how to conduct the class. This is essentially a script that tutors can use in the classroom. In online environments with multiple e-tutors it would seem that a discussion forum for e-tutors where they can ask questions of the content expert and of each other would be useful. The e-tutors could also be encouraged to discuss strategies or activities that worked well, as well as seeking advice when needed. These forums could be used in conjunction with the lesson plans to ensure the depth and breadth of content is covered as intended by the content and assessment developer(s). By supporting e-tutors in this way they gain the confidence to challenge students to explore the curriculum to enhance their learning in the long term.

A further lesson learned from this study is that teaching staff experienced in online learning should take a more proactive role in assisting tutors to become effective etutors, in conjunction with the professional development opportunities available. 'As we become increasingly dependent upon online modes of communication and teaching in higher education, it is incumbent upon universities to not only provide ongoing and comprehensive professional development in online learning but to encourage participation through dedicated time release and/or other forms of work relief in order for staff to effectively participate' (Dixon et al., 2008; p.264). Some tertiary institutions have invested in online professional development with multimedia resources to demonstrate good teaching practice (see for example Bell \& Morris, 2009).

\section{Conclusions}

Through an examination of the role of the e-tutor in facilitating online student discussions in a wholly online unit, this study has drawn attention to the responsibilities and the role of the e-tutor. This role is quite unique and needs to be well defined if the expectations of the teaching staff and students are to be met.

The roles e-tutors are expected to adopt must be continually reviewed. Tutors must be trained in online facilitation and 'need to be encouraged to weave, to create patterns, build the network and make links, summarise and rearrange material, to add real value to the student's online experiences' (Cox et. al, 2000; p.15). The need for preparing teachers for the online environment is well supported in the literature (see for example, Wilson \& Stacey, 2004; McDonald \& Reushle, 2002; Harris \& Sandor, 2007). Ongoing mentoring by experienced online teachers can assist tutors to put into practice the requirements of an e-tutor's role. Ongoing mentoring can also assure teaching staff that e-tutors are performing their roles effectively.

It is recommended that appropriate and regular professional development is made available to all teaching staff, particularly if tutors are to become effective e-tutors, so 
that they can take full advantage of the opportunities available to support student learning in e-learning environments. Even experienced teachers require support to continually adapt and improve their skills as the technologies continue to evolve.

\section{References}

Bell, A. \& Morris, G. (2009). Engaging professional learning in online environments. Australasian Journal of Educational Technology, 25(5), 799-713. http: / / www.ascilite.org.au/ajet/ajet25/bell.html

Berge, Z. L. (1995). Facilitating computer conferencing: Recommendations from the field. Educational Technology, 35(1), 22-30.

Brown, C. (2002). Simple and effective - teacher roles remain a powerful framework to embed ICT within the practice of teaching. Proceedings of Society for Information Technology and Teacher Education International Conference 2002, Chesapeake, VA: AACE.

Cheung, W. S. \& Hew, K. F. (2008). Examining facilitators' habits of mind and learners' participation. In Hello! Where are you in the landscape of educational technology? Proceedings ascilite Melbourne 2008. http:/ / www.ascilite.org.au/conferences/melbourne08/ procs/ cheung.pdf

Cheung, W.S. \& Hew, K. F. (2010). Examining facilitators' habits of mind in an asynchronous online discussion environment: A two cases study. Australasian Journal of Educational Technology, 26(1), 123-132. http:/ / www.ascilite.org.au/ajet/ajet26/ cheung.html

Coldwell, J. (2010). Benchmarking flexible education: Paper 3 - International Practice. Deakin University Internal Report.

Collison, G., Elbaum, B., Haavind, S. \& Tinker, R. (2000). Facilitating online learning: Effective strategies for moderators. Madison, WI, USA: Atwood Publishing.

Conrad, D. (2004). University instructors' reflections on their first online teaching experiences. Journal of Asynchronous Learning Networks, 8(2), 31-44. [verified 10 Jul 2010] http: / / citeseerx.ist.psu.edu / viewdoc / download?doi=10.1.1.110.1754\&rep=rep1\&type =pdf

Cosetti, A. (2002). Tutoring: A different background for the same role. In Proceedings of Ed-Media 2002, Denver, AACE. 355-356.

Cox, E. S., Clark, W. P., Heath, H. \& Plumpton, B. (2000). Key facilitation skills for effective online discussion groups: Herding cats through Piccadilly Circus. Proceedings from Distance Education: An open question, 11-13 September, Adelaide, SA. [verified 10 Jul 2010]. http: / / www.unisanet.unisa.edu.au/cccc/papers/refereed/paper11/paper11-1.htm

Craig, A., Goold A., Coldwell, J. \& Mustard, J. (2008). Perceptions of roles and responsibilities in online learning: A case study. Interdisciplinary Journal of E-Learning and Learning Objects, 4, 205-223. http: / /ijklo.org/Volume4/IJELLOv4p205-223Craig510.pdf

Denis, B., Watland, P., Pirotte, S. \& Verday, N. (2004). Roles and competencies of the e-tutor. Networked Learning Conference 2004. [viewed 14 Mar 2009, verified 10 Jul 2010]. http: / / www.networkedlearning conference.org.uk/past/nlc2004/proceedings/symposia/s ymposium6/denis_et_al.htm

Directorate-General for Education and Culture (2004-2005). Guidelines for E-Tutors in MultiCultural Collaborative and Synchronous (MCCS) teaching situations. [viewed 31 Aug 2009, not found 10 Jul 2010]. http:/ / www.if.insa-lyon.fr/projects / etutir / guidelines / content.html 
Dixon, R., Dixon, K. \& Axmann, M. (2008). Online student centred discussion: Creating a collaborative learning environment. In Hello! Where are you in the landscape of educational technology? Proceedings ascilite Melbourne 2008.

http: / / ascilite.org.au/conferences/ melbourne08/procs/ dixon.pdf

Ellis, R., Goodyear, P., O'Hara, A. \& Prosser, M. (2007). The university student experience of face-to-face and online discussions: Coherence, reflection and meaning. ALT-J: Research in Learning Technology, 15(1), 83-97. [verified 10 Jul 2010] http:/ / repository.alt.ac.uk/715/1/ALT_JVol15_No1_2007_The_university_student_experie.pdf

Goodyear, P., Salmon, G., Spector, J., Steeples, C. \& Tickner, S. (2001). Competencies for online teaching. Educational Technology Research and Development, 49, 65-72.

Harris, N. \& Sandor, M. (2007). Developing online discussion forums as student centred peer elearning environments. In Hello! Where are you in the landscape of educational technology? Proceedings ascilite Melbourne 2008. http: / / www.ascilite.org.au/conferences/melbourne08/ procs/harris.pdf

Hootstein, E. (2002). Wearing four pairs of shoes: The roles of e-learning facilitators. In G. Richards (Ed), Proceedings of World Conference on E-Learning in Corporate, Government, Healthcare, and Higher Education. Chesapeake, VA: AACE, 457-462.

Kaur, A., Fadzil, M. \& Ahmed, A. (2005). Supporting autonomous learning: How effective are online tutors? In P. Kommers \& G. Richards (Eds), Proceedings of World Conference on Educational Multimedia, Hypermedia and Telecommunications 2005. Chesapeake, VA: AACE, 2856-2863.

Kim, Y. J., Lee, S. \& Lim, M. (2010). An analysis on tutor's roles for facilitating critical thinking in online discussion. In Z. Abas et al.(Eds.), Proceedings of Global Learn Asia Pacific 2010. AACE. 4232-4241. [viewed 28 June 2010]. http:// www.editlib.org/p/34524

King, A. (1993). From a sage on the stage to guide on the side. College Teaching, 41(1), 30-35.

Lim, K. \& Lee, D. Y. (2008). A comprehensive approach to the teacher's role in computer supported learning environments. Proceedings of Society for Information Technology and Teacher Education International Conference, Chesapeake, VA: AACE, 4208-4213.

Maor, D. (2008). Changing relationship: Who is the learner and who is the teacher in the online educational landscape? Australasian Journal of Educational Technology, 24(5), 627-638. http: / / www.ascilite.org.au/ajet/ajet24/maor.html

McDonald, J. \& Reushle, S. (2002). Charting the role of the online teacher in higher education: Winds of change. In Winds of change in the sea of learning: Proceedings ascilite Auckland 2002. http:/ / www.ascilite.org.au/conferences/auckland02/proceedings / papers / 095.pdf

McQuiggan, C. A. (2007). The role of faculty development in online teaching's potential to question teaching beliefs and assumptions. Online Journal of Distance Learning Administration, 10(3). http: / / www.westga.edu/ distance/ ojdla/ fall103/ mcquiggan103.htm

Mortera-Gutiérrez, F. (2008). The role of online tutors, online learning, and best teaching practices within "Investiga EGE": A Mexican higher education case Study. In C. Bonk et al. (Eds.), Proceedings of World Conference on E-Learning in Corporate, Government, Healthcare, and Higher Education 2008. Cheapeake, VA: AACE. 1872-1877.

Morris, L., Xu, H. \& Finnegan, C. (2005). Roles of faculty in teaching asynchronous undergraduate courses. Journal of Asynchronous Learning Networks, 9(1), 65-82. [verified $10 \mathrm{Jul}$ 2010] http:/ / www.msmc.la.edu/include/learning_resources/online_course_environment / online_teaching/v9n1_faculty.pdf 
National Tertiary Education Union (2007). State of the sector. South Melbourne: Policy Research Unit. http: / / archive.nteu.org.au/publications/other/state_of_the_sector/pdf [viewed 20 June 2010, verified $10 \mathrm{Jul} 2010]$.

$\mathrm{Ng}$, C. S. L. \& Cheung, W. S. (2007). Comparing face to face, tutor led discussion and online discussion in the classroom. Australasian Journal of Educational Technology, 23(4), 455-469. http: / / www.ascilite.org.au/ajet/ajet23/ng.html

O'Neil, T. (2006). How distance education has changed teaching and the role of the instructor. Proceedings ISECON 2007, v24 (Pittsburgh). [verified $10 \mathrm{Jul}$ 2010] http: / / proc.isecon.org/2007 / 2542/ ISECON.2007.ONeil.pdf

Ramsden, P. (1992). Learning to teach in higher education. London, Routledge.

Salmon, G. (2002). Keynote: Pedagogical requirements of virtual learning environments (VLEs): PETS and PLANETS. The 24 hour University: stretching the limits, UCISA TLIG-SDG User Support Conference, Leeds UK. [verified 10 Jul 2010] http:/ / www.atimod.com/research/presentations/Salmonleeds.htm

Salmon, G. (2003). E-moderating: The key to teaching and learning online. Routledge Falmer.

White, C., Murphy, L., Shelley, M. \& Baumann, U. (2005). Towards an understanding of attributes and expertise in distance language teaching: Tutor maxims. In T. Evans, P. Smith \& E. Stacey (Eds), Research in Distance Education 6: Revised papers from the 6th Research in Distance Education conference, Deakin University, Geelong, 83-97.

Wilson, G. \& Stacey, E. (2004). Online interaction impacts on learning: teaching the teachers to teach online. Australasian Journal of Educational Technology, 20(1), 33-48. http:/ / www.ascilite.org.au/ajet/ajet20/wilson.html

\section{Ms Annegret Goold}

School of Information Technology, Deakin University, Geelong VIC 3217, Australia Email: annegret.goold@deakin.edu.au

Dr Jo Coldwell, Associate Head (Teaching and Learning)

School of Information Technology, Deakin University, Geelong VIC 3217, Australia

Email: jo.coldwell@deakin.edu.au

Web: http: / www.deakin.edu.au/scitech/it/about/staff-

profiles / display /index.php?username=jojo

Dr Annemieke Craig, Senior Lecturer

School of Information Systems, Deakin University, Geelong VIC 3217, Australia

Email: annemieke.craig@deakin.edu.au

Web: http:/ / www.deakin.edu.au/buslaw/infosys/staff/profiles/craig.php 